\title{
About Trinocladus Raineri, 1922: when some Permocalculus (Gymnocodiacean algae) reveal to be Triploporellacean algae (Revision of the Jesse Harlan Johnson Collection. Part 5)
}

\author{
Bruno Granier $^{1,2} \mathbb{C} \cdot$ Ioan I. Bucur ${ }^{3} \cdot$ Dimas Dias-Brito $^{4}$
}

Received: 25 March 2017 / Accepted: 10 August 2017 / Published online: 5 September 2017

(c) Springer-Verlag GmbH Germany 2017

\begin{abstract}
The Upper Cretaceous-Paleogene genus Trinocladus that is based on T. tripolitanus Raineri, 1922, originally described from Libyan material, is morphologically well constrained. Its species are commonly distinguished on the basis of their biometrics. However, the narrow Gaussian distribution reported for some measurements may result from post-mortem dynamic sorting as suggested by a review of the surrounding microfacies. An examination of Brazilian material of the type-species suggests a slightly club-shaped thallus morphology. Two "false Permocalculus" species originally described by Johnson and the type-material of which has been reexamined are formally reascribed to the genus Trinocladus. T. budaensis, the smallest one, has slightly club-shaped thallus, too. T. elliotti is poorly mineralized and insufficiently documented. In addition to $T$.
\end{abstract}

Bruno Granier

bgranier@univ-brest.fr; bgranier@ku.edu

Ioan I. Bucur

ioan.bucur@ubbcluj.ro

Dimas Dias-Brito

dimasdb@rc.unesp.br

1 Dépt. STU, Fac. Sci. Tech, UBO, CS 93837, 29238 Brest, France

2 Department of Ecology and Evolutionary Biology, The University of Kansas, 1200 Sunnyside Avenue, Lawrence, KS 66045, USA

3 Department of Geology and Center for Integrated Geological Studies, Babeş-Bolyai University, M. Kogălniceanu str., 1, 400084 Cluj-Napoca, Romania

4 Center for Geosciences Applied to Petroleum (UNESPetro) and Departamento de Geologia Aplicada, UNESP-Universidade Estadual Paulista, Av. 24 A, no. 1515, Bela Vista, Caixa Postal 178, Rio Claro, SP CEP 13506-900, Brazil tripolitanus, Raineri described a tiny species which was later revised by Pia, i.e., Dissocladella ondulata. D. bonardii, a name recently introduced by Radoičić et al. and which is based on Raineri's original material, is considered here as an objective junior synonym of $D$. ondulata.

Keywords Cretaceous - Dasycladales - Trinocladus . Dissocladella $\cdot$ Biometric limitation

\section{Introduction}

When studying some fossil "calcareous" algae, the impact of various factors, among which a weak mineralization in the form of metastable aragonite, a centripetal micritization, the mechanical sorting of the bioclasts derived from them and their mechanical abrasion, may significantly affect the three-dimensional reconstructions of their thalli. In the case studied, we must bear in mind that the outer cortical layer of some Dasycladales, e.g., Trinocladus Raineri, 1922, vaguely ressembles that of some Halimedaceae or Gymnocodiaceae (both Bryopsidales), e.g., Permocalculus Elliott, 1955. In addition, weak mineralizations on the main axis and on the proximal part of the laterals for the Dasycladales or on the medullar filaments for the Bryopsidales may result in a poor preservation of the inner parts of the original aragonitic coatings and can explain the common misinterpretation of the original algal architectures.

For instance, as for the "Inventory of the fossil Dasycladalean algae" (Deloffre and Granier 1992; Granier and Deloffre 1993), the genus Trinocladus Raineri, 1922, was supposedly known from the Late Jurassic to the Oligocene (with a hiatus in the earliest Cretaceous). With the exclusion of some Jurassic specimens that were erroneouly ascribed to T. perplexus Elliott 1955, and later redescribed 
as Thyrsoporella pseudoperplexa Granier et Braik 2002, the stratigraphic range of the genus is currently restricted to the "mid-" Cretaceous-Oligocene interval. Although some forms were erroneously interpreted as representatives of the genus Trinocladus, the opposite is also true. The present paper, which is the fifth contribution to the "Revision of the Jesse Harlan Johnson Collection" (Granier et al. 2013, 2017; Granier and Dias-Brito 2016; Basso and Granier 2017), also re-examines the case of two Trinocladus species that Johnson (Johnson and Kaska 1965; Johnson 1968) erroneously ascribed to the genus Permocalculus.

\section{Material}

\section{The material studied comes from four collections hosted in three countries}

1. The J. Pfender Collection is hosted at Sorbonne University-Pierre et Marie Curie University, Paris (France). We re-examined three thin sections from Turonian strata in Provence, SE France:

No. 90 "Barres Le Revest, Trinocladus tripolitanus, Boueinia",

No. 90 bis "W de Costebelle, Trinocladus ondulatus", No. 90 ter "W Costebelle, Trinocladus". This material was previously revised by Massieux (in Pfender and Massieux 1966).

2. The J.H. Johnson Collection is hosted at the Smithsonian National Museum of Natural History, Washington, D.C. (U.S.A.). It comprises one thin section U.S.N.M. No. 42547 from the "mid-" Cretaceous (AlbianCenomanian) of Guatemala and a set of eleven thin sections U.S.N.M. Nos. 42607-42617 from the Buda Fm (Cenomanian) of Texas, U.S.A. Each set is associated to a species described by Johnson (1968; Johnson and Kaska 1965).

3. The P. Tibana Collection was temporarily hosted with the UNESPetro's collections at the UNESP-Universidade Estadual Paulista, Rio Claro, S.P. (Brazil). Tibana's material is from the Bonfim Fm (Cenomanian) of the Barreirinhas basin; thin sections Nos. 281-282 have a well-sorted grain-supported fabric whereas thin section No. 68-53 has a mud-supported fabric. The remaining set of fifteen thin sections found at the UNESPetro (Nos. 87B, 88A\&B, 89B, 91B, 92A\&B, 93A\&B, 94A\&B, $95 A \& B$, and $96 A \& B$ ) are from the Jandaira Fm (Turonian-lower Campanian) of the Potiguar basin; their fabric is mud-supported and their texture is that of bio- clastic wackestones. Part of this material was illustrated by Granier (2015).

\section{The genus Trinocladus and its type-species}

The type-species is T. tripolitanus Raineri, 1922. It was originally documented by two figures (Raineri 1922, Pl. III, figs. 15-16). The first figure (Raineri 1922, Pl. III, fig. 15), that Pia selected as the "type" (lectotype), is a transverse section that displays the typical arrangement with three orders of pores, left behind in lieu of the laterals. According to Pia (1936) who first revised Raineri's material, the primary pores are "approximatively club-shaped"; "the secondary pores repeat on a smaller scale the shape of the primary pores, narrow at their bases, expanding outward"; in turn, "the tertiary pores are short and slender", possibly widening outward to form an external cortex. The second figure (Raineri 1922, Pl. III, fig. 16) is a long oblique section, that provides a glimpse of what tangential and axial sections look like. However, in this figure, only two orders of pores are visible. This pattern is not typical of Trinocladus, but it is characteristic of Dissocladella (Pia in L.R. Rao et Pia, 1936).

\section{The Libyan Dissocladella controversy}

According to Pia (1936) Trinocladus is an intermediary genus between Dissocladella and Thyrsoporella. (see Bassoullet et al. 1978). Besides Trinocladus tripolitanus, Raineri (1922, p. 75-76, Pl. III, figs. 7-11) introduced a "Neomeris cretacea Stein. var. ondulata". Pia (1936), who re-examined Raineri's material, treated this variety as a genuine species, but he reascribed it to the genus Dissocladella. Incidentally he slightly modified the spelling of the specific epithet from ondulata to undulata.

According to the I.C.B.N. (2012, Art. 8 and 40), there was no need for the authors to select a "type (holotype, lectotype, or neotype) of a name of a species" before 1 January 1958. The five original figures were considered as syntypes and there was a need to select one of them as the lectotype. Although one of the five original Raineri's specimens (1922, Pl. III, fig. 7) was the most poorly preserved, Radoicic et al. (2005, Pl. I, fig. 1) unfortunately selected it as the lectotype. Regarding this specimen, Pia (1936) even stated that it "is possibly some other fossil, not an alga". In addition, Radoičić et al. (2005) reascribed it with doubt to the genus Trinocladus Raineri 1922, and, as they said, it "is expected to remain ill-defined". Regarding the four remaining specimens (Raineri 1922, Pl. III, figs. 8-11), this group of authors (Radoičić et al. 2005) assigned them to a species that they 
newly introduced, i.e., Dissocladella bonardii Radoičić et al. 2005.

Due to the above mentioned issues and to the untenable conflict with Pia's (1936) protologue (i.e., the species was described as a Dissocladella, with two orders of laterals, not as a Trinocladus, with three orders of laterals) and the strong opinion of Radoičić et al. (2005) about the specimen they selected as lectotype, a new lectotype designation is then requested. This new lectotype designation should supersede Radoičić et al.' designation. Accordingly we select here another Raineri's specimen (1922, Pl. III, fig. 8) as the new lectotype of the species Dissocladella ondulata (Raineri, 1922), Pia 1936. Consequently, D. bonardii Radoičić et al. 2005 , should be treated as an objective junior synonym of the Raineri's taxon.

Both species D. ondulata (Raineri, 1922) and Trinocladus tripolitanus Raineri, 1922, were originally described in the same publication, from the close localities, from the Cenomanian of Libya. While describing one of her two specimens of T. tripolitanus, Raineri (1922, Pl. III, fig. 16) pointed out that "Due soli rami secondarii sono visibili per ciascun ramo primario ma non completi, mancano i rami di terzo ordine forse per la fragilità della loro costituzione" (Primary branches are partially preserved; each has only two visible secondary branches; there are no tertiary branches as a result of their fragile structure). Similarly Pia (1936) reported some specimens of $T$. tripolitanus having locally only primary pores, which correspond to the first order laterals, preserved (Pia 1936, Pl. 2, figs. 2, 4-5). Both of these authors conclude that it might be related to mechanical abrasion. Inward micritization may also have contributed in masking some outer features. In addition, according to Pia (1936), "we have to keep in mind that some whorls never had secondary and tertiary twigs. Probably this was not a peculiarity of certain plants, but of certains parts, presumably the lower ones, of each plant". In conclusion, there is one last option left regarding Dissocladella ondulata and Trinocladus tripolitanus: both species could be synonymous, which implies that sections ascribed to Dissocladella ondulata would then represents the smallest, poorly or incompletely preserved sections of Trinocladus tripolitanus or another $T$. sp., the tertiary pores of which are hardly visible or a matter of interpretation.

From the J. Pfender Collection, Massieux (in Pfender and Massieux 1966) illustrates a "Trinocladus tripolitanus" (op. cit., Pl. 2, fig. 1; here Fig. 1b) with "extrêmement petites" dimensions-tertiary pores are hardly visible, if any-, a first "Dissocladella undulata" (op.cit., Pl. 2, fig. 2; here Fig. 1c) and a second "Dissocladella undulata" (op.cit., Pl. 2, fig. 3; here Fig. 1d). The first two sections (op.cit., Pl. 2, figs. 1-2; here Fig. 1b, c) match with the morphology and the measurements of D. ondulata; the third section (op.cit., Pl. 2, fig. 3; here Fig. 1d) is probably a representative of the
Bryopsidales (with both larger medullar filaments and cortical filaments). These forms are associated to other algae, e.g., Boueinia sp. and Marinella lugeoni Pfender, 1939, in well-sorted grain-supported fabrics.

\section{New biometric observations on Brazilian Trinocladus tripolitanus specimens}

We could not examine Raineri's material, which was previously revised by Pia (1936), but the species is quite common in the Upper Cretaceous strata of Brazil. Our specimens come from two localities: one in the Barreirinhas basin (Bonfim Fm, Cenomanian: Figs. 2a-c, 3b, c) and one in the Potiguar basin (Jandaira Fm, Turonian-lower Campanian: Figs. 2d, 3a, d). Our material, particularly the Cenomanian material from the Barreirinhas basin, is very similar to the one illustrated by Pia (1936).

The key measurements ( $D$ outer diameter; $d$ inner diameter; $d / D$ : ratio in \%) of the three specimens measured by Pia (1936):

- Specimen $1, D=470 \mu \mathrm{m}, d=160 \mu \mathrm{m}, d / D=34 \%$ (possibly abraded),

- Specimen $2, D=610 \mu \mathrm{m}, d=140 \mu \mathrm{m}, d / D=23 \%$,

- Specimen 3, $D=680 \mu \mathrm{m}, d=190 \mu \mathrm{m}, d / D=28 \%$ (Table 1),

fit well with those of our Bonfim specimens (Figs. 2a-c, $3 b, c)$ :

- $D=685 \pm 105 \mu \mathrm{m}$ (13 measurements), $D$ min $=525 \mu \mathrm{m}$, $D \max =890 \mu \mathrm{m}$

- $d=150 \pm 25 \mu \mathrm{m}$ (10 measurements), $d \min =120 \mu \mathrm{m}$, $d \max =175 \mu \mathrm{m}$,

- $d / D=22 \pm 5 \%$ (10 measurements), $d / D$ min $=16 \%, d / D$ $\max =30 \%$ (Table 1$)$.

The Jandaira specimens (Figs. 2d, 3a, d) show more variability, notably with occurrences of larger specimens (smaller specimens are similar to the ones of the Bonfim Fm). The grain-supported facies of the Bonfim Fm are dominantly bioclastic. In addition to the algae, i.e., Boueinia sp., Neomeris sp. and Trinocladus tripolitanus, the bioclasts comprise some Pieninia oblonga Borza et Misik, 1976, which are Alcyonarian spicules (Granier 1986). In contrast the facies of the Jandaira Fm are mud-supported. In addition to the algae, i.e., Permocalculus sp., Terquemella sp., Neomeris sp. and Trinocladus tripolitanus, the bioclasts comprise some foraminifera, e.g., Rhapidyonina liburnica (Stache, 1889) and Quinqueloculina ssp. It is suggested here that the narrower distribution of sizes observed in Bonfim compared to the wider distribution observed in Jandaira probably results 

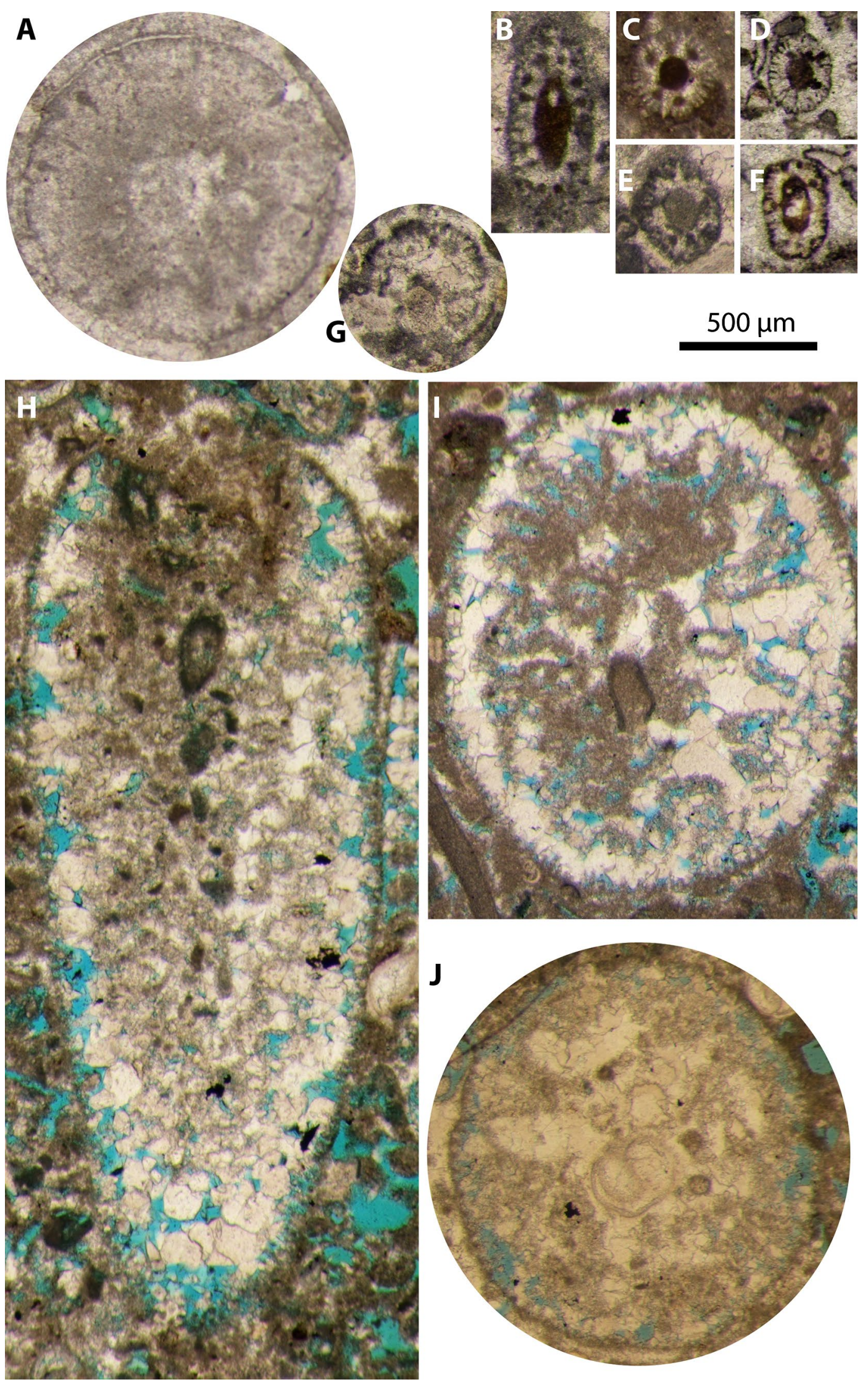
४Fig. 1 a Trinocladus elliotti (Johnson et Kaska ex Deloffre 1992, non 1965) Radoičić 2006: transverse section, Johnson Collection, USNM no. 42547, Albian or Cenomanian, Guatemala. b-g Pfender Collection, Cenomanian, Provence France: b, c and e, f Dissocladella undulata; b oblique section, "Trinocladus tripolitanus Raineri, 1922" according to Massieux (Pfender and Massieux 1966, pl. 2, fig. 1), Pfender no. 90; c transverse section, "Dissocladella undulata Raineri, 1922" according to Massieux (Pfender and Massieux, 1966, pl. 2, fig. 2), Pfender no. 90ter; e) oblique section, Pfender no. 90; F oblique section, Pfender no. 90bis; $\mathbf{d}$ random section of a representative of the Bryopsidales, "Trinocladus tripolitanus Raineri, 1922" according to Massieux (Pfender and Massieux, 1966, pl. 2, fig. 3), Pfender no. 90bis; $\mathbf{g}$ indeterminate alga, Pfender no. 90. h, i Sarosiella ferremollis Segonzac, 1976, non 1972, Granier Collection, Paleocene, Libya: h longitudinal oblique section, no. A30(32); i oblique section, no. A29(65); j transverse section, no. A30(29)

from a mechanical sorting in higher energy environments, i.e., Bonfim Barreirinhas barrier versus Jandaira Potiguar lagoon.

In conclusion, the key measurements combining both the Bonfim and Jandaira values provide a better, representative image of the species variability:

- $D=775 \pm 205 \mu \mathrm{m}$ (21 measurements), $D \min =525 \mu \mathrm{m}$, $D \max =1325 \mu \mathrm{m}$,

- $d=190 \pm 70 \mu \mathrm{m}$ (16 measurements), $d \min =120 \mu \mathrm{m}$, $d \max =305 \mu \mathrm{m}$,

- $d / D=26 \pm 8 \%$ (16 measurements), $d / D$ min $=16 \%, d / D$ $\max =42 \%$ (Table 1$)$.

Ideally new species should be defined from samples that did not undergo any sorting to prevent a misinterpretation of the alga sizes and morphology. In the case studied, although Pia (1936) was "under the impression that" the thallus "was of a rather slender, cylindrical shape", the association of sections ranging in diameter from 525 to $1325 \mu \mathrm{m}$ suggests the thallus had a slightly club-shaped morphology instead as originally reported by Raineri (1922: "cilindro-clavata").

Additional measurements include $h$ (spacing of two successive verticils) ranging from 90 to $155 \mu \mathrm{m}, l_{1}$ (maximum length the primary pores) up to $300 \mu \mathrm{m}, p_{1}$ (diameter of the primary pores at their larger part) from 60 to $145 \mu \mathrm{m}, l_{2}$ (maximum length the secondary pores) from 100 to $150 \mu \mathrm{m}$, $p_{2}$ (diameter of the secondary pores at their larger part) from 30 to $55 \mu \mathrm{m}, l_{3}$ (maximum length the tertiary pores) up to $30 \mu \mathrm{m}$. Although we have found some very large specimens, i.e., with an outer diameter more than twice the diameters given by Pia (1936), we did not find small specimens with $D$ ranging from 240 to $320 \mu \mathrm{m}$ that he identified as "Dissocladella undulata". Therefore, the hypothesis that $D$. ondulata and Trinocladus tripolitanus could be synonymous is not supported by our finds. In Libya, both species occur in the same stratigraphic interval, but probably come from discrete localities (as a matter of fact, the thin section numbers of
Raineri's collection given by Pia overlap but never coincide: 5, 16-18 and 21 for Dissocladella ondulata; 7, 9, and 12 for Trinocladus tripolitanus).

\section{The false Permocalculus species}

Two authors (i.e., Bucur 1994, and Radoičić 2006), without reexamining the type-material, and followers (Granier et al. 2017) pointed out that two Permocalculus (Gymnocodiaceae, Bryopsidales) species described by Johnson could be reassigned to the genus Trinocladus (Triploporellaceae, Dasycladales). Both species were nomina nuda because they were lacking the identification of an holotype. In both cases, there was a need to define a lectotype before introducing the new combination. Finally, a prerequisite would have been to re-examine the type-material.

The first author of the present paper (B.G.) got the opportunity to study Johnson's material stored in the premices of the Smithsonian National Museum of Natural History, Washington, D.C. "Permocalculus budaensis" is present in thin sections U.S.N.M. Nos. 42607-42610, 42612-42613, and 42617; "P. elliotti" is found in one single thin section U.S.N.M. No. 42547.

Family Triploporellaceae (Pia, 1920)

Tribe Triploporelleae (Pia, 1920)

Genus Trinocladus Raineri, 1922

Type: T. tripolitanus Raineri, 1922, p. 79-83, Pl. III, figs. 15 (lectotype selected by Pia 1936)-16.

Synonym: Sarosiella Segonzac, 1976, non 1972, based on S. ferremollis Segonzac, 1976, non 1972, p. 394-396, Pl. XIX, figs. 1 (lectotype selected by Segonzac 1976), 2-6. S. ferremollis Segonzac, 1976, non 1972, is a Trinocladus with long primaries and relatively short secondaries.

Note: Unfortunately, the type-material and most of Segonzac's Collection are definitely lost, thrown away by Charles-François Boudouresque, Aix-Marseilles University. We illustrate here some specimens from the Paleocene of Libya (Fig. $1 \mathrm{~h}-\mathrm{j}$ ) have a $D=1375 \pm 165 \mu \mathrm{m}$ with $D \min =1030 \mu \mathrm{m}$ and $D \max =1590 \mu \mathrm{m}$.

Trinocladus budaensis Johnson ex Granier et al., this work, non 1968

(Figure 4a-k)

nom. nud. 1968 Permocalculus budaensis n.sp. Johnson, p. 8, Pl. 1, figs. 2, 3 (USNM no. 42607) and 4-5 (USNM no. 42608).

nom. nud. 1968 Permocalculus budaensis var. pygmaea n.var. Johnson, p. 9, Pl. 2, fig. 2 (USNM no. 42613). nom. nud. 1969 Permocalculus budaensis Johnson, 1968. Johnson, p. 27, not illustrated.

nom. nud. 1969 Permocalculus budaensis var. pygmaea Johnson, 1968. Johnson, p. 27, not illustrated. 

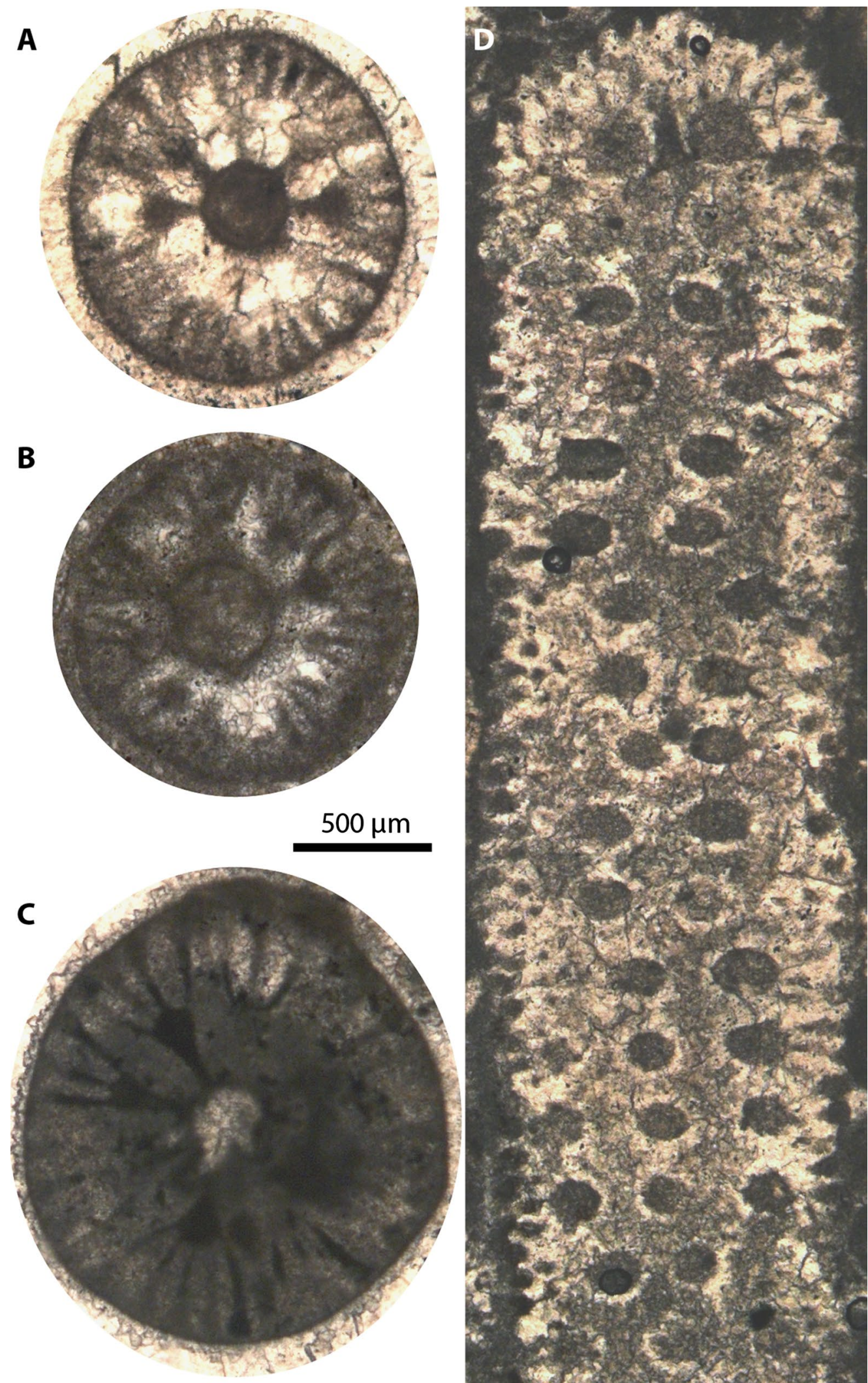

Fig. 2 Trinocladus tripolitanus Raineri, 1922: a-c Barreirinhas, Tibana Collection, Cenomanian, Brazil: a transverse section, no. 282; b no. 68-53; c no. 282; d Rio do Carmo, no. J087B, Dias-Brito Collection, Turonian—lower Campanian, Brazil 

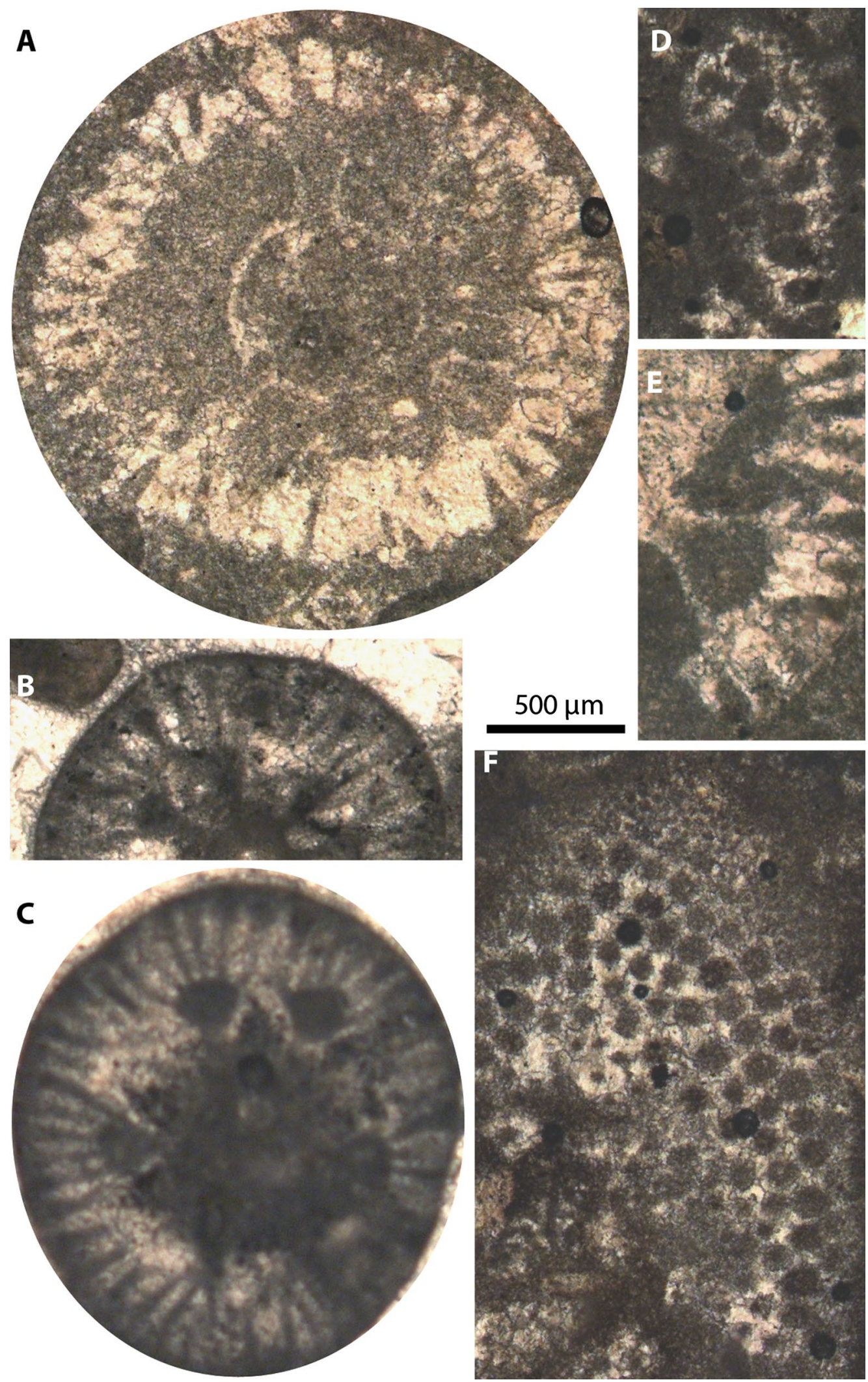

Fig. 3 Trinocladus tripolitanus Raineri, 1922: a, d-f Rio do Carmo, Dias-Brito Collection, Turonian—lower Campanian, Brazil: a no. J088B; d, e no. J094B; f no. J093A; b, c Barreirinhas, Tibana Collection, no. 282, Tibana Collection, Cenomanian, Brazil 
nom. nud. 1992 Permocalculus budaensis Johnson, 1968. Deloffre, p. 25, Pl. 1, fig. 5 (excerpt from Johnson 1968, Pl. 1, fig. 5).

non nom. nud. 1994 Permocalculus budaensis Johnson, 1968. Bucur, p. 19-20, Pl. 7, Fig. 9.

Type: According to Johnson (1968), the "type slide" is "U.S.N.M. 42607, which contains several specimens", actually two illustrated by the author (op. cit., Pl. 1, figs. 2-3; here Figs. 4e, 3j). There was no identification of an holotype and we select here as the lectotype (op. cit., Pl. 1, fig. 3; here Fig. 4j) amongst the specimens illustrated by Johnson.

\section{Measurements}

- $D=440$ to $675 \mu \mathrm{m}$ according to Johnson (1968),

- $D=585 \pm 125 \mu \mathrm{m}$ (23 measurements), $D$ min $=310 \mu \mathrm{m}$, $D \max =845 \mu \mathrm{m}$,

- $d=125 \pm 30 \mu \mathrm{m}$ (16 measurements), $d \min =80 \mu \mathrm{m}, d$ $\max =290 \mu \mathrm{m}$,

- $d / D=23 \pm 5 \%$ (16 measurements), $d / D$ min $=16 \%, d / D$ $\max =33 \%$.

Additional measurements include $h$ ranging from 100 to $165 \mu \mathrm{m}, l_{1}$ up to $155 \mu \mathrm{m}, p_{1}$ from 45 to $65 \mu \mathrm{m}, l_{2}$ from 70 to $130 \mu \mathrm{m}, p_{2}$ up to $40 \mu \mathrm{m}, l_{3}$ up to $50 \mu \mathrm{m}, p_{3}$ up to $20 \mu \mathrm{m}$.

Although the facies are grain-supported (grainstone texture), the mechanical sorting cannot be demonstrated due to a limited number of thin sections, each of which possibly represents discrete grain size sortings in relation to different levels of energy. The set of specimens with diameters ranging from 310 to $845 \mu \mathrm{m}$ suggests the thallus has a slightly club-shaped morphology.

Association and stratigraphy: This species is associated to algae [Heteroporella lepina (Praturlon, 1967), Cymopolia sp., Neomeris sp., Cylindroporella? sp., Terquemella sp., Permocalculus sp., Ethelia alba (Pfender, 1936), and Marinella lugeoni Pfender, 1939], foraminifera (Lituolidae,
Fig. 4 Trinocladus budaensis Johnson ex Granier et al., this work, non 1968, Johnson Collection, upper Albian-Cenomanian, Texas, USA: a, c-f, h and j USNM no. 42607; b, g, i and $\mathbf{l}$ USNM no. 42608; k USNM no. 42613. a slim subtransverse section (? lower part of a thallus) on the lower left corner and large oblique section (? upper part of a thallus) on the upper right corner; b longitudinal oblique section, "long section" according to Johnson (1968, pl. 1, fig. 5); c deep tangential section; d subaxial section; e longitudinal oblique section, "oblique long section" according to Johnson (1968, pl. 1, Fig. 2); f longitudinal oblique section; $\mathbf{g}$ tangential oblique section; $\mathbf{h}$ subtransverse section at the bottom with a Neomeris remain at the top; i transverse section; $\mathbf{j}$ oblique section, "oblique cross section" according to Johnson (1968, pl. 1, fig. 3); k two transverse sections, "Permocalculus budaensis pygmaea" according to Johnson (1968, pl. 2, fig. 2; I subtransverse section, "cross section" according to Johnson (1968, pl. 1, fig. 4) "Permocalculus budaensis pygmaea" (Trinocladus budaensis Johnson ex Granier et al., this work, non 1968)

Coscinoconus sp., Nummoloculina sp., Cuneolina sp., Favusella sp.), and Pieninia oblonga Borza et Mišik, 1976. This assemblage is characteristic of the uppermost Albian-Cenomanian.

Trinocladus elliotti (Johnson et Kaska ex Deloffre, 1992, non 1965) Radoičić, 2006

nom. nud. 1965 Permocalculus elliotti n.sp. Johnson and Kaska, p. 65-66, Pl. 5, figs. 1-5 (USNM no. 42547).

nom. nud. 1969 Permocalculus elliotti Johnson et Kaska, 1965.- Johnson, p. 26, Pl. 16, figs. 1-5 (excerpt from Johnson and Kaska 1965, Pl. 5, figs. 1-5).

1992 Permocalculus elliotti Johnson et Kaska, 1965. Deloffre, p. 26, Pl. 1, fig. 2 (excerpt from Johnson and Kaska 1965, Pl. 5, fig. 4)

2006 Trinocladus elliotti (Johnson in Johnson et Kaska, 1965), n. comb. Radoičić, p. 70, not illustrated

Type: According to Johnson and Kaska (1965), the type is "Slide 18587 which contains six segments and numerous fragments. 18587 = U.S.N.M. No. 42547”. There was no identification of an holotype and Deloffre (1992: Pl. 1, fig. 2; here Fig. 5i) selected a lectotype amongst the specimens

Table 1 Inner and outer diameters of the main axis of some specimens or species cited in the text

\begin{tabular}{|c|c|c|c|c|c|c|c|c|c|c|c|c|}
\hline Trinocladus & $D \min (\mu \mathrm{m})$ & $D \max (\mu \mathrm{m})$ & $D$ & $n D$ & $d \min$ & $d \max (\mu \mathrm{m})$ & $d(\mu \mathrm{m})$ & $n d$ & $d / D \min$ & $d / D \max$ & $d / D$ & $n d / D$ \\
\hline \multicolumn{13}{|l|}{ T. tripolitanus } \\
\hline Pia 1936, no. 1 & & & 470 & & & & 160 & & & & 34 & \\
\hline Pia 1936 , no. 2 & & & 610 & & & & 140 & & & & 23 & \\
\hline Pia 1936 , no. 3 & & & 680 & & & & 190 & & & & 28 & \\
\hline Bonfim & 525 & 890 & $605 \pm 105$ & 13 & 120 & 175 & $150 \pm 25$ & 10 & $16 \%$ & $30 \%$ & $22 \pm 5 \%$ & 10 \\
\hline Jandaira & 525 & 1325 & $775 \pm 205$ & 21 & 120 & 305 & $190 \pm 70$ & 16 & $16 \%$ & $42 \%$ & $26 \pm 8 \%$ & 16 \\
\hline T. ferremollis & 1030 & 1590 & $1375 \pm 165$ & 10 & & & & & & & & \\
\hline T. budaensis & 310 & 845 & $585 \pm 125$ & 23 & 80 & 290 & $125 \pm 30$ & 16 & $16 \%$ & $33 \%$ & $23 \pm 5 \%$ & 16 \\
\hline T. elliotti & 935 & 1235 & & & & & & & & & & \\
\hline T. divnae & 710 & 1947 & & & 126 & 177 & & & & & & \\
\hline
\end{tabular}

$D$ outer diameter, $d$ : inner diameter, $\min$ minimum, $\max$ maximum, $n$ number of specimens measured 


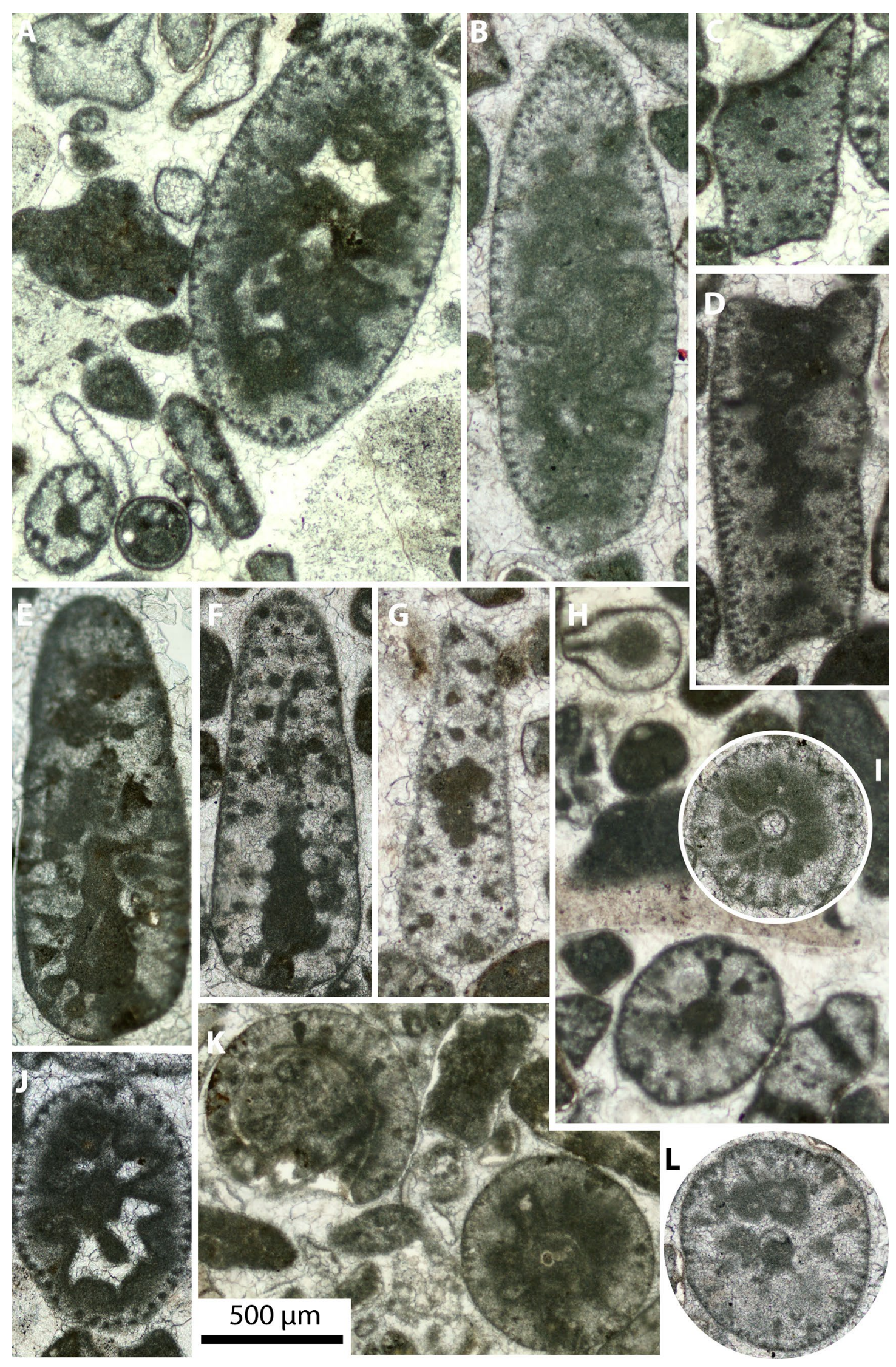



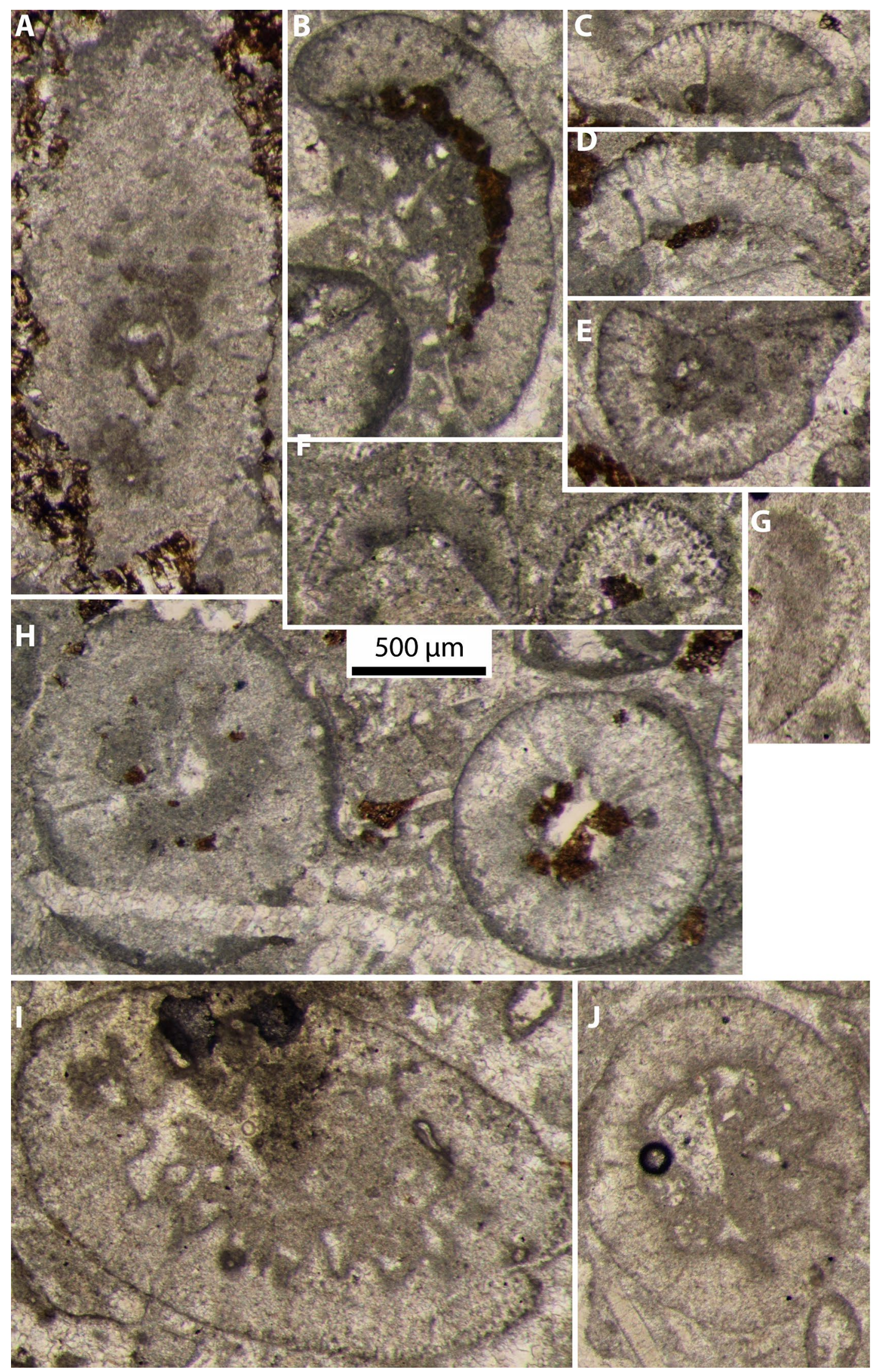
4Fig. 5 Trinocladus elliotti (Johnson et Kaska ex Deloffre, 1992, non 1965) Radoičić, 2006, Johnson Collection, USNM no. 42547, Albian or Cenomanian, Guatemala: a longitudinal oblique section, "long section" according to Johnson and Kaska (1965, pl. 5, fig. 2); b broken oblique section; $\mathbf{c}$ small broken piece showing division of the laterals (primaries to tertiaries), "detail of a fragment showing sporangium" according to Johnson and Kaska (1965, pl. 5, fig. 1); d small broken piece showing division of the laterals (mostly secondaries and tertiaries); e broken piece showing division of the laterals (primaries to tertiaries), "detail (...) with several sporangia" according to Johnson and Kaska (1965, pl. 5, fig. 5); f, g oblique sections showing division of the laterals (mostly secondaries and tertiaries); $\mathbf{h}$ two transverse sections showing division of the laterals (primaries to tertiaries), "cross sections" according to Johnson and Kaska (1965, pl. 5, fig. 3); i oblique section, "long section" according to Johnson and Kaska (1965, pl. 5, fig. 4); j subtransverse section

illustrated by Johnson and Kaska (1965: Pl. 5, fig. 4; here Fig. 5i).

Measurements: $D=825-1100 \mu \mathrm{m}$ according to Johnson and Kaska (1965), 935-1235 $\mu \mathrm{m}$ according to us. $l_{1}$ more than $110 \mu \mathrm{m}, p_{1}$ up to $95 \mu \mathrm{m}, l_{2}$ from 120 to $185 \mu \mathrm{m}, p_{2}$ up to $35 \mu \mathrm{m}, l_{3}$ from 65 to $110 \mu \mathrm{m}$. We do not providee measurements for $d$ (and $d / D$ ) because the main axis is not mineralized and there is an irregularly shaped axial cavity instead.

Although the facies is very bioclastic, grains are mudsupported, which is indicative of a favorable environment to preserve calcareous algae. However, because there is only one thin section, data are insufficient to elaborate further on the algal thallus morphology.

Association and stratigraphy: in the unique thin section USNM 42 547, this form is associated to Elianella elegans Pfender et Basse, 1948, and Marinella lugeoni Pfender, 1939. According to Johnson and Kaska (1965), the sample comes from lowermost Cretaceous or uppermost Jurassic strata; however we consider that it is either Albian or Cenomanian in age.

\section{Conclusions}

1. Because the genus Trinocladus Raineri, 1922, is morphologically well constrained (e.g., with a typical threefold division of its laterals), biometrics are requisite in order to distinguish species (Table 1). However we must keep in mind that the narrow Gaussian distribution observed for some algal measurements may actually result from a post-mortem dynamic sorting by size. For instance, the use of biometrics on Brazilian material of T. tripolitanus Raineri, 1922, suggests that the thallus morphology was slightly club-shaped, not cylindrical as previously thought on the basis of the Libyan material. Low-energy facies with mud-supported fabrics are more favorable to better estimate the real range of size variations within a species, but this same material might be micritized and poorly preserved. High-energy facies with grain-supported fabrics will artificially narrow the range of size variations; in addition, this material might be mechanically abraded. These examples help demonstrating, if necessary, that taphonomy, particularly the depositional facies, should always be taken into account when describing or re-examining many fossil calcareous algae.

2. Regarding the systematics, two "false Permocalculus" species (Bryopsidales, Gymnocodiaceae) are reascribed to the genus Trinocladus (Dasycladales, Triploporellaceae). T. budaensis Granier et al. (this work) is smaller than both T. tripolitanus Raineri, 1922, i.e., the genus type-species, and T. elliotti (Deloffre, 1992), which is characterized by a weak mineralization (its main axis was not mineralized). In addition, we found that Dissocladella bonardii Radoičić et al., 2005, should be treated as an objective junior synonym of $D$. ondulata (Raineri, 1922), a species that accompanies to Trinocladus tripolitanus in Cenomanian strata of Libya.

Acknowledgements The first author (B.G.) is grateful for the support provided by the successive curators of paleontological collections at the Sorbonne University-Pierre et Marie Curie University, first Jean-Pierre Bellier, then Isabelle Rouget. In 2012, he benefited from a Smithsonian Fellowship allowing him to investigate the J. Harlan Johnson Collection stored in the premises of the Smithsonian Institution. He would like to thank the staff of the Department of Paleobiology at the Smithsonian National Museum of Natural History and particularly William A. DiMichele and Jonathan G. Wingerath for their hospitality and having facilitated his work there. Later in 2015, he was also the laureate of a Franco-Brazilian professorship at the UNESPetro in Rio Claro (São Paulo State, Brazil) that enabled him to work on Brazilian material. This research is associated with the "Carbonatos do Brasil Project" linked to the Brazilian Sedimentology/Stratigraphy Net sponsored by Petrobras.

\section{References}

Basso D, Granier B (2017) Johnson and Kaska 1965 fossil Coralline algae from Guatemala (revision of the Jesse Harlan Johnson Collection, part 4). Rivista Italiana di Paleontologia e Stratigrafia

Bassoullet J-P, Bernier P, Conrad MA, Deloffre R, Jaffrezo M (1978) Les algues Dasycladales du Jurassique et du Crétacé. Geobios, Mémoire spécial 2:1-330

Bucur II (1994) Lower Cretaceous Halimedaceae and Gymnocodiaceae from Southern Carpathians and Apuseni Mountains (Romania) and the systematic position of the Gymnocodiaceae. Beiträge zur Paläontologie 19:113-127

Deloffre R (1992) Révision des Gymnocodiaceae (algues rouges, Permien-Miocène). Taxinomie, biostratigraphie, paléobiogéographie. $3^{\mathrm{e}}$ Partie. Rev Micropaléontol 35(1):23-37

Deloffre R, Granier B (1992) Inventaire des Algues Dasycladales fossiles. $\mathrm{I}^{\circ}$ partie- Les Algues Dasycladales du Tertiaire. Rev Paléobiol 11(2):331-356

Elliott GF (1955) The Permian alga Gymnocodium. Micropaleontology 1:83-90 
Granier B (1986) Les Pieninia oblonga Borza \& Misik, 1976, sontelles des sclérites d'Alcyonaires ? Rev Micropaléontologie 29(2):103-108

Granier B (2015) Algas calcárias marinhas bentônicas no Cretáceo do Brasil. In: Dias-Brito D, Tibana P (eds) Atlas dos Calcários do Cretáceo do Brasil: um Atlas. Obra 1. IGCE/UNESP/Rio Claro, UNESPetro, pp 518-567

Granier B, Braik F (2002) Thyrsoporella pseudoperplexa n. sp., une Dasycladacée (algue verte calcaire) du Jurassique supérieur téthysien. In: Bucur II, Filipescu S (eds) Research advances in calcareous algae and microbial carbonates.- Presa Universitara Clujeana, Cluj-Napoca, pp 127-133

Granier B, Deloffre R (1993) Inventaire des Algues Dasycladales fossiles. $\mathrm{II}^{\circ}$ partie- Les Algues Dasycladales du Jurassique et du Crétacé. Rev Paléobiol 12(1):19-65

Granier B, Dias-Brito D (2016) On the fossil alga Marinella lugeoni Pfender, 1939, nom. cons., and its seven unfortunate avatars. Revision of the Juliette Pfender Collection. Part 2. Revision of the Jesse Harlan Johnson Collection. Part 2. Carnets Geol 16(7):231245. doi:10.4267/2042/59922

Granier B, Radoičić R, Drobne K (2013) Revision of the Jesse Harlan Johnson Collection. Part 1. Some fossil Dasycladales from Guatemala. Carnets Geol CG2013_A07:281-301. doi:10.4267/2042/51824

Granier B, Basso D, Vachard D (2017) Les algues "calcaires" fossiles (Permien-Miocène) du Guatémala. Catalogue critique de la Collection de J.H. Johnson. 3e partie. Archives des Sciences 69(1):29-54

ICBN (2012) International Code of Nomenclature for algae, fungi, and plants (Melbourne Code). Koeltz Scientific Books. http://www. iapt-taxon.org/nomen/main.php Accessed 25 March 2017

Johnson JH (1968) Lower Cretaceous algae from Texas. Professional Contributions of the Colorado School of Mines 4: i-vii + 1-71

Johnson JH (1969) A review of the Lower Cretaceous algae. Professional Contributions of the Colorado School of Mines 6: $\mathrm{i}-\mathrm{xvi}+1-180$
Johnson JH, Kaska HV (1965) Fossil algae from Guatemala. Professional Contributions of the Colorado School of Mines 1: i-xii $+1-152$

Pfender J, Massieux M (1966) Les algues du Nummulitique égyptien et des terrains crétacés-éocènes de quelques régions mésogéennes. Première partie. Revue de Micropaléontologie 9(2):111-132

Pia J (1920) Die Siphonae verticillatae vom Karbon bis zur Kreide. Abh Zool Bot Ges Wien 11(2):1-263

Pia J (1936) Calcareous green algae from the Upper Cretaceous of Tripoli (North Africa). J Paleontol 10(1):3-13

Radoičić R (2006) Trinocladus divnae and Montiella filipovici-a new species (Dasycladales, green algae) from the Upper Cretaceous of the Mountain Paštrik (Mirdita Zone). Annales géologiques de la Péninsule balkanique 6:65-87

Radoičić R, Conrad MA, Carras N (2005) Observations on Neomeris cretacea var. undulata Raineri followed by Dissocladella bonardii, n. sp. (Dasycladales, green algae). Rev Paléobiol 24(1):311-317

Raineri R (1922) Alghe sifonee fossili della Libia. Atti della Società Italiana di Scienze Naturali e del Museo Civico di Storia Naturale in Milano LX:72-86

Rao LR, Pia J (1936) Fossil algae from the uppermost Cretaceous beds (the Niniyur Group) of the Trichinopoly district, S. India. Memoirs of the Geological Survey of India, Palæontologia Indica, New Series XXI(4): 1-49

Segonzac G (1972) Description d'un nouveau genre d'algue calcaire du "Sparnacien" des Pyrénées, de la Haute-Garonne, de l'Aude et de l'Ariège: Sarosiella. Bulletin de la Société d'Histoire Naturelle de Toulouse 108(3-4):394-396

Segonzac G (1976) Dasycladacées nouvelles ou peu connues du Thanétien des Pyrénées. Bulletin de la Société d'Histoire Naturelle de Toulouse 112(1-2):123-136 